\title{
Biological activity of monoquaternary ammonium compounds based on 3-substituted quinuclidine: A short review
}

\author{
RENATA ODŽAK \\ MATILDA ŠPRUNG* \\ University of Split, Faculty of Science, \\ Department of Chemistry, R. Boškovića 33, \\ 21000 Split, Croatia \\ *Correspondance: \\ Matilda Šprung \\ e-mail: msprung@pmfst.hr \\ ORCID: 0000-0001-5008-2700
}

Keywords: quaternary ammonium compounds; quinuclidine; 3-substituted quinuclidine; biological activity; antimicrobial potential
Received March 30, 2020

Revised May 28, 2020

Accepted May 29, 2020

\begin{abstract}
:
Quaternary ammonium compounds (QACs) have a long-known application as antiseptics and disinfectants applied in various industries such as pharmaceutical, agricultural and food industry. Given the alarming number of $Q A C$ s resistant bacteria, there is an urgent need to develop new QACs with broad-spectrum antimicrobial activities and low tendency to trigger bacterial resistance. One recently proposed approach to develop new QACs is based on quaternization of natural products, which proved to be successful. Quinuclidine is an interesting natural precursor find to be a part of the structure of biologically active cinchona alkaloids. In addition to the well-established medicinal and pharmaceutical potential of 3-substituted quinuclidines, QACs based on 3-substituted quinuclidines, have only recently been shown to exhibit a significant antimicrobial activity. Most importantly, these compounds exhibit low toxicity toward normal human cell lines, which opens up a new chapter in the QACs field ensuring further investigation of possible therapeutic application of 3-substituted quinuclidine based QACs.
\end{abstract}

\section{INTRODUCTION}

B acterial resistance has become one of the major healthcare problems. B This problem has been associated with a widespread misuse of antibiotics in the agricultural and food industries as well as in hospitals wherein up to $50 \%$ of prescribed antibiotics are either unnecessary or not appropriately administered $(1,2)$. The rate of the bacterial resistance is growing at such an alarming pace that the World Health Organization (WHO), European Commission, and Center for the disease control (CDC) all run public healthcare campaigns to raise awareness about this worldwide problem (3). In line with this, an enormous effort of scientific community has been directed to develop strategies to combat bacterial resistance and to search for new antimicrobial drugs.

Quaternary ammonium compounds (QACs) have long ago been recognized as powerful antimicrobial agents (1). The development of QACs started in 1935 when Domagk first reported antimicrobial activity of benzyldodecyldimethyl ammonium chloride (4), the core of what would later be known as BAC (benzalkonium chloride). This ingredient soon after became used by surgeons for hand and surgical surface disinfection (2). Currently, there are four QACs found as components of many commercial products (Figure 1). 


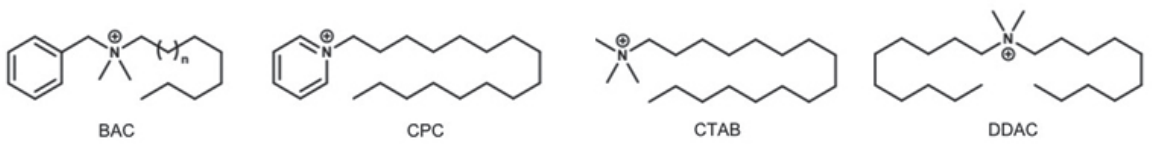

Figure 1. Structures of the leading commercial QACs: benzylmethyldodecyl amonium chloride (BAC), cetyltrimethylammonium bromide (CTAB), cetypyridinium chloride (CPC) and dimethyl dodecyl ammonium chloride (DDAC)

QACs are amphiphilic molecules of general chemical structure $\mathrm{N}^{+} \mathrm{R}_{1} \mathrm{R}_{2} \mathrm{R}_{3} \mathrm{R}_{4} \mathrm{X}^{-}$( $\mathrm{R}$ : hydrogen atom, plain alkyl group or alkyl group substituted with other functional groups; $\mathrm{X}^{-}$: anion). Owing to their chemical nature, QACs are often compared with amphiphilic antimicrobial peptides that target cell membrane (5). By analogy, it is generally believed that their antimicrobial activity is based on the electrostatic interaction between the positively charged nitrogen atom and negatively charged groups on the bacterial cell surface. Once this interaction is established, the alkyl part of the QACs penetrates through the bacterial membrane, causing membrane perforation and osmotic imbalance which ultimately leads to the bacterial cell lysis $(1,6)$.

Since QACs act on a bacterial membrane, resistance to these compounds has been considered as almost impossible. However, it has been shown that the resistance toward QACs is developing at such an alarming pace that in 2012 as much as 83\% of methicillin resistant Staphylococcus aureus (MRSA) isolates were resistant to all commercial QACs (7). It has been proposed that chemical stability and a widespread use of these compounds are the main contributors to the development of resistance. Each year approximately 700,000 tons of QACs is released into the environment with BAC having a lifetime of 9 months. For these reasons, environmental bacteria that are persistently exposed to sub-lethal concentrations of QACs have developed resistance $(8,9)$. The resistance is based in either a change of membrane composition or in expression of Qac efflux pumps (1, 10-13). Although, recent research suggests that beside Qac efflux pumps, there are other unknown mechanism(s) of resistance (14), the most extensively studied one is the qac resistance mechanism. The qac resistance mechanism is based on Qac efflux pumps that are under negative control of the QacR transcriptional regulator (15). Upon QACs penetration into the bacterial cell, QacR binds to quaternary ammonium compound which leads to conformational change and dissociation of QacR from the DNA. Once Qac pumps are expressed, QACs are expelled from the cells preserving the bacterial cell integrity $(1,9-12)$.

Therefore, an urgent elucidation of resistance mechanism(s) and development of new potent QACs that are specifically designed to avoid bacterial resistance are in the main focus of the future research in the field.

Until now, numerous scientific papers have been published about altering QACs structures, such as modification of aryl and alkyl part of the molecule or alteration of the charge state (1). In addition to distinct class of QACs derived from commercially available structures, other scaffolds have also been investigated, some of which include natural product-based, pyridine-, cyclic- and linearstructure based scaffolds (8). Modifications of alkyl chain length and substitutions of aromatic ring hydrogen with chlorine, methyl and ethyl groups have also been made in order to optimize QACs activity (16-18). In addition to efforts concerning optimization of QACs activity, researchers have proposed that QACs variants more prone to spontaneous or induced decomposition might be less susceptible to trigger bacterial resistance as bacteria would be less exposed to these agents. Indeed, several studies have shown that QACs variants modified with ester and amide functional groups or liable spacer groups are less stable and thus represent a lower threat to the environment (9, 19, 20). However, when comparing ester- and amide-containing QACs variants, it was evident that ester-variants had diminished antimicrobial activity and were less stable in aqueous solution which makes them more prone to decomposition. These and other authors have concluded that stability of QACs is tightly related to their bactericidal activity, so any modification of stability needs to be strictly and carefully regulated $(9,21)$.

Special effort in the course of the past ten years has been made by Wuest and Minbiole groups that managed to develop some of the most powerful QACs. Their compounds have two or even more ammonium centers (bisand multi-QACs) with different lengths of alkyl side chains $(5,6,9,22-24)$. The authors have hypothesized that QACs with more than one positive ammonium center could be more selective toward bacterial cells and could be less prone to resistance. In a series of such studies, Wuest and Minbiole groups have managed to prove that bisQACs are indeed superior structures in terms of activity, but no significant improvement in antimicrobial activity was observed for muliQACs variants.

Despite these valuable efforts, only few studies so far reported development of QACs by derivatization of natural precursors which is very surprising given the fact that nature is an inexhaustible source of bioactive structures. By exploring quaternization of nicotine and quinine, Joyce et al. showed that natural product derivatization could be a promising strategy in new QACs discovery (25). Similarly, recently published study showed successful quaternization of $\beta$-carboline alkaloid, canthin-6-one, resulting in derivatives that have good antimicrobial activity (26). 


\section{Quinuclidine - natural heterocyclic product}

Quinuclidine is a bicyclic compound find as a part of bioactive alkaloids isolated from the bark of the cinchona tree. Given its long tradition in the folk medicine, quinuclidine pose an attractive target for further research in the field of medicinal chemistry. Today, quinuclidine based drugs are some of the most important FDA approved medicines with different treatment application. However, antimicrobial potential of quinuclidine has just recently start to be the subject of scientific investigations.

\section{Chemistry}

Heterocyclic natural product, quinuclidine (1-azabyciclo[2.2.2] octane) is a very rigid structure consisting of saturated bicyclic system with a bridge headed nitrogen atom (27). It is notable for its high symmetry and for the insignificant bond energy. The above features of the structure of quinuclidine explain some of the physical and chemical properties and peculiarities of quinuclidine and various derivatives of the bicyclic system. For example, unsubstituted quinuclidine is a volatile crystalline compound with a high melting point $\left(158^{\circ} \mathrm{C}\right)$. Disturbing the symmetry of the quinuclidine molecule (by introduction of an alkyl substituents into the quinuclidine ring, for example) decreases the melting point (4-methylquinuclidine, m.p. $49-50^{\circ} \mathrm{C}$ ). The peculiarities of the structure of the quinuclidine molecule give rise to the remarkable stability of this compound. Quinuclidine is not changed by heating with concentrated mineral acid $(\mathrm{HCl}, \mathrm{HI}$, $\mathrm{H}_{2} \mathrm{SO}_{4}, \mathrm{HNO}_{3}$ ) or by treatment with potassium permanganate (28).

The nitrogen lone-pair electrons are $s p^{3}$-hybridized and are not subject to steric crowding. The basicity of
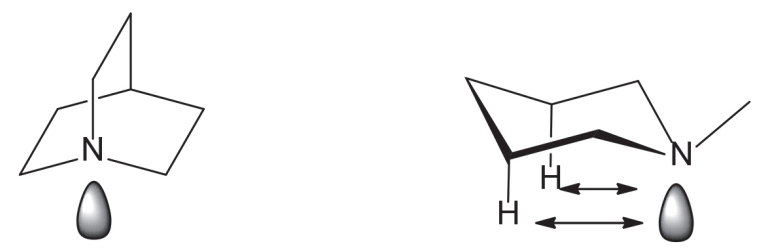

Figure 2. Influence of adjacent hydrogen atoms on the nucleophilicity of tertiary piperidine quinuclidine, which depends on the electron density at the nitrogen atom, is very similar to that observed in aliphatic amines and $N$-alkylpiperidines. Quinuclidine, like other tertiary amines, easily forms salts with mineral and organic acids. Also, with alkyl or aryl halides quinuclidine forms quaternary ammonium compounds with higher rates of reaction for quinuclidine with alkyl halides than with tertiary aliphatic amines. These findings can be explained by the almost total absence of steric hindrance at the nitrogen lone pair of the bicyclic compound (Figure 2).

In substituted quinuclidine, the basicity decreases due to inductive effect of the substituted group (Figure 3). In the array of 3-substituted quinuclidines, the reactivity has been correlated to their $\mathrm{p} K a$ values whereby unsubstituted quinuclidine, exert the highest $\mathrm{p} K a$ value and is the most active (27).

\section{Biological activity of QACs based on 3-substituted quinuclidine}

Quinuclidine was first discovered as a scaffold of the cinchona tree alkaloids, quinine, quinidine, cinchonidine and cinchonine, that have long tradition in folk medicine as drugs for malaria and cardiac arrhythmia (Figure 4) (27).

In addition to the well-known therapeutic potential of cinchona alkaloids, quinuclidine based compounds have been shown to exhibit a wide range of other biological activities such as anticholinergic, antioxidative, antiparasitic, antibacterial and antitumor, which makes this compound extremely interesting for further research (29-35).

The best explored biological activity of quinuclidine is that against $\alpha 7$-nicotin acetylcholine receptor $(\alpha 7 \mathrm{nAChR})$ as evidenced by its several derivatives that are currently in the second phase of the clinical trial for treatment of schizophrenia and Alzheimer's disease (36-38). Nowadays, compounds with quinuclidine pose some of the currently most important FDA-approved drugs, such as Azasetron, Benzoclidine, Palonosetron, Solifenacin, and Quinupramine (39).

3 -substituted quinuclidines are a subtype of quinuclidine derived compounds that are especially interesting due to their wide range of different pharmacological prop-

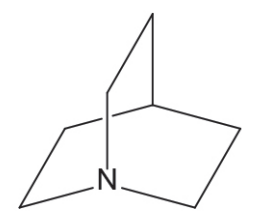

$\mathrm{pKa}$

11.3

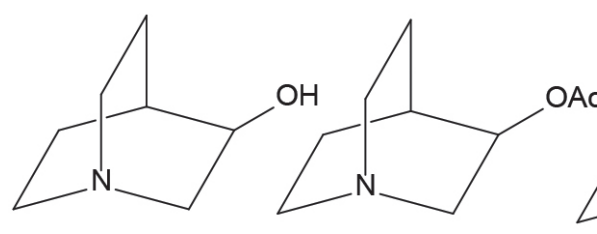

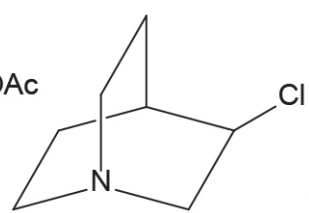

8.9

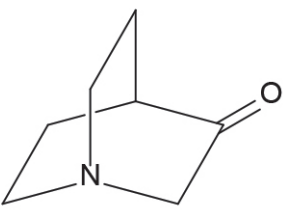

7.2

Figure 3. The basicity of quinuclidine and their 3-substituted derivatives with associated $p K a$ values 
<smiles>C=CC1CN2CCC1C([C@H](O)c1ccnc3ccc(OC)cc13)C2</smiles>

Quinine<smiles>C=CC1CN2CCC1C[C@H]2[C@H](O)c1ccnc2ccccc12</smiles>

Cinchonidine<smiles>C=CC1CN2CCC1C2[C@H](O)c1ccnc2ccc(OC)cc12</smiles>

Quinidine<smiles>C=CC1CN2CCC1C2[C@H](O)c1ccnc2ccccc12</smiles>

Cinchonine
Figure 4. Quinuclidine containing cinchona alkaloids: quinine, quinidine, cinchonidine and cinchonine

erties. Well-known drugs, Aceclidine and Temekhin, are examples of 3-substituted quinuclidines available on the market whereby Aceclidine is used for treatment of ocular hypertension in glaucoma suffering patients and Temekhin as a ganglion inhibitor (40-42). Beside acting on the cholinergic system, some quinuclidine containing compounds have been shown to affect other organ systems in the body, acting as antidepressants, stimulators of the central nervous system or cough suppressants (40).

Since 3 -substituted quinuclidines generally contain common pharmacophores such as positive nitrogen atom, carbonyl group and aromatic ring, they have been extensively investigated as antagonists of the 5-hydroxytriptaminic receptor ${ }_{3}\left(5-\mathrm{HT}_{3}\right)$ (42). This receptor is a ligandgated ion channel that regulates membrane potential of the central nervous system cells. In recent years, much attention has been paid to $5-\mathrm{HT}_{3}$ receptor antagonists, namely zacopride and RG12915, as these agents have been found to be effective antiemetic drugs for chemotherapy side effect treatment (43).

3 -substituted quinuclidines have an asymmetric carbon atom and can therefore be synthesized as either racemates or as single enantiomers. As such racemates are generally less favorable due to possible different biological effects of an individual enantiomer, ranging from either lower activity of a less active enantiomer to complete loss of response or to an increased toxicity $(41,42)$. Therefore, numerous studies have been focused on finding chemical or biocatalytic methods for separation of enantiomers in the racemic mixture (44). For the separation of various 3 -substituted quinuclidine enantiomers, two biocatalysts have been extensively investigated, namely, acetylcholinesterase and butyrylcholinesterase $(41,42,45-48)(41,42$, 45-48). Instead successful resolution of enantiomers, these studies have identified 3 -substituted quinuclidines as reactivators or inhibitors of acetylcholinesterase and butyrylcholinesterase. Therefore, it has been proposed that these compounds could be antidotes for poisoning with organophosphorus reagents.

\section{Antimicrobial activity of 3-substituted quinuclidine QACs}

Quaternary ammonium compounds are powerful antimicrobial agents, mostly used as disinfectants or antiseptics in various industries. Given the narrow number and the widespread bacterial resistance to all QACs currently available on the market, there is an urgent need to develop new such compounds. Development of QACs by quaternization of natural products has been proposed by Joyce et al. (25). This study motivated us to further explore quaternization of 3-substituted quinuclidine QACs and to explore their antimicrobial activity.

The first reported study on quinuclidine based QACs and their antimicrobial potential was reported by our group in 2016 (49). The authors have synthesized 3-hydroxyquinuclidine bromides with variable length of alkyl side chains, containing 12, 14 and 16 carbon atoms (Figure 5). The newly synthesized compounds had good adsorption potential and low critical micellar concentrations. Most importantly, all compounds had good antimicrobial potential against both, Gram-positive and Gram-negative bacterial strains. The authors conclude that a bicyclic head with oxime functional group and the number of carbon atoms in alkyl chains, have an important effect on physicochemical properties affecting hydrophobicity and hydrophilicity of synthesized surfactants. Given the lower solubility of derivatives with higher number of carbon atoms in alkyl side chains, derivative containing 12 carbon atoms had considerably higher bioactivity.

In 2017 Odžak et al. reported synthesis of another series of quaternary ammonium compounds based on 3 -substituted quinuclidines containing benzyl functional group and different substituents at para position (Figure 6) (50). Soon after, Bazina et al. reported synthesis of

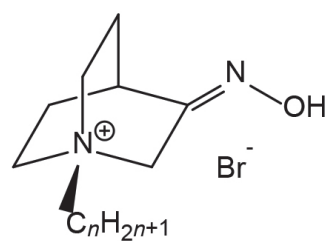

$(n=12,14,16)$

Figure 5. Quaternary ammonium compounds based on 3-hydroxyiminoquinuclidine 

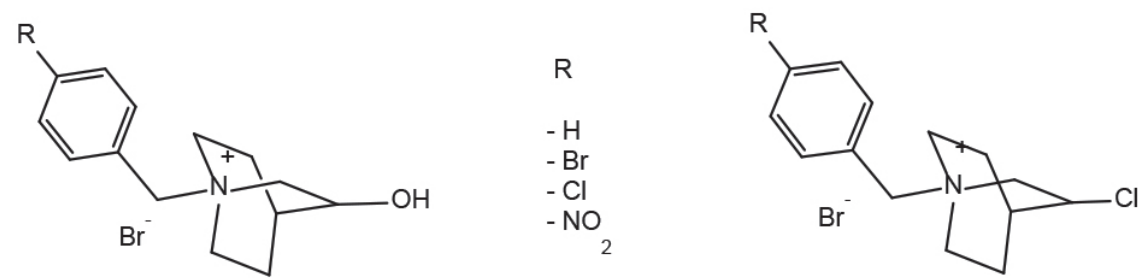

Figure 6. Quaternary ammonium compounds based on 3-hydroxoquinuclidine and 3-chloroquinuclidine.

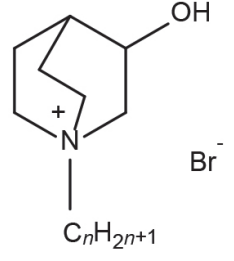

$(n=3,4,6,8,10,12,14)$

Figure 7. Quaternary ammonium compounds based on 3-hydroxyquinuclidine with alkyl chain

QACs based on 3-substituted quinuclidines with alkyl side chain of variable length (Figure 7) (51).

These studies have shown that quaternization improves quinuclidine bioactivity by several hundred folds, albeit derivatives with aryl substituents typically had lower antimicrobial activity than their alkyl counterparts. However, authors have shown that alkyl chain is an important part of the structure, most probably essential for penetration process involving bacterial cell membrane. In this series of 3-substituted quinuclidines (Figure 7), derivatives with longer chains tend to be more active and had good antimicrobial potential against Gram-positive and Gram-negative strains (51).

However, the authors have observed better activity against Gram-positive bacteria than Gram-negative suggesting that membrane composition might influence QACs-membrane interaction. Moreover, the derivative with the longest alkyl chain (QOH-C14) have been identified as a potential candidate due to the lowest MIC values against several bacterial strains especially against opportunistic pathogen Staphylococcus aureus. QOH-C14 had good potential against bacterial biofilms and was capable to inhibit $S$. aureus growth at even subMIC concentrations. Additionally, authors have shown that QOHC14 interacts with bacterial membrane, most probably by proposed mechanism which includes electrostatic interaction between bacterial membrane and positive nitrogen on QOH-C14. When this interaction is established, alkyl chain portion can insert in a membrane leading to membrane perforation and cell death. Given the potential application of these compounds, cytotoxicity assay was performed using normal human cell lines and it was ob- served that human cells are susceptible to higher concentration of QOH-C14, but this value was several times lower than MIC suggesting that QOH-C14 might represent a good starting point in new QACs discovery (51). Moreover, Odžak et al. and Bošković et al. have observed good antioxidative potential for aryl and alkyl substituted 3-quinuclidine QACs, which might be relevant for other possible applications or additional mode of action mechanisms $(32,33)$.

Kastelić et al. have synthesized ten new $N$-alkyl and $N$-aryl derivatives of 3-hydroxyiminoquinuclidine (Figure 8) (39).

The best activity was recorded for compounds para$\mathrm{ClC}_{6} \mathrm{H}_{5} \mathrm{CH}_{2}-$ (5), meta- $\mathrm{ClC}_{6} \mathrm{H}_{5} \mathrm{CH}_{2}{ }^{-}$(6), para$\mathrm{BrC}_{6} \mathrm{H}_{5} \mathrm{CH}_{2}-(9)$, meta- $\mathrm{BrC}_{6} \mathrm{H}_{5} \mathrm{CH}_{2}$ - (10) with MIC values ranging from 0.25 to $256 \mu \mathrm{g} / \mathrm{mL}$. However, despite usually seen better activity against Gram-positive bacteria, here the authors have reported better bioactivity against Gram-negative strains, which might be relevant for future design of QACs with broader activity spectrum. In addition, authors have concluded that quaternary $N$ benzyl derivatives of quinuclidine oximes are, in general, more potent and have broader antimicrobial activity than their core molecule, qox, but position of substituents at benzyl moiety does not seem to be an important factor affecting antimicrobial efficacy. Most important, the compounds have not shown toxicity toward normal human cell lines and have been tested for intracellular ROS generation potential. The ROS generating potential was found to be different for each cell line tested. Lower concentration of 5, 6, 9 and 10 derivatives in $\mathrm{HaCaT}$ cell line

R
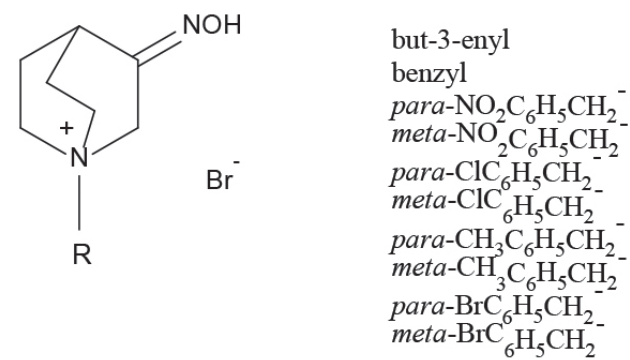

Figure 8. Quaternary ammonium compounds based on 3-hydroxyiminoquinuclidine (qox) 
(human keratinocytes) induce generation of ROS while in HMEC cell line, ROS production was not concentration dependent. This was found to be in correlation with catalase activity. In $\mathrm{HaCaT}$ cells, catalase activity did not change but results with human mammary epithelial cell, HMEC were less conclusive due to similar effect of DMSO and compounds.

\section{REFERENCES}

1. JENNINGS MC, MINBIOLE KPC, WUEST WM 2016 Quaternary ammonium compounds: An antimicrobial mainstay and platform for innovation to address bacterial resistance. ACS Infect Dis 1(7): 288-303 https://doi.org/10.1021/acsinfecdis.5b00047

2. BUFFET-BATAILLON S, TATTEVIN P, BONNAURE-MALLET M, JOLIVET-GOUGEON A 2012 Emergence of resistance to antibacterial agents: The role of quaternary ammonium compounds - A critical review. Int J Antimicrob Agents 39(5): 381-389 https://doi.org/10.1016/j.ijantimicag.2012.01.011

3. BLANCHET M, BORSELLI D, RODALLEC A, PEIRETTI F, VIDAL N, BOLLA J M, DIGIORGIO C, MORRISON KR, WUEST WM, BRUNEL JM 2018 Claramines: A new class of broad-spectrum antimicrobial agents with bimodal activity. ChemMedChem 13(10): 1018-1027 https://doi.org/10.1002/ cmdc. 201800073

4. DOMAGK G 1935 Eine neue Klasse von Desinfektionsmitteln. Dtsch Medizinische Wochenschrift 61(21): 829-832 https://doi. org/10.1055/s-0028-1129654

5. FORMAN ME, JENNINGS MC, WUEST W M, MINBIOLE KPC 2016 Building a better quaternary ammonium compound (QAC): branched tetracationic antiseptic amphiphiles. ChemMedChem 11(13): 1401-1405 https://doi.org/10.1002/ cmdc. 201600176

6. BLACK JW, JENNINGS MC, AZAREWICZ J, PANIAK T J, GRENIER MC, WUEST WM, MINBIOLE KPC 2014 TMEDA-derived biscationic amphiphiles: An economical preparation of potent antibacterial agents. Bioorganic Med Chem Lett 24(1): 99-102 https://doi.org/10.1016/j.bmcl.2013.11.070

7. JENNINGS MC, BUTTARO BA, MINBIOLE KPC, WUEST WM 2016 Bioorganic investigation of multicationic antimicrobials to combat qac-resistant Staphylococcus aureus. ACS Infect Dis 1(7): 304-309 https://doi.org/10.1021/acsinfecdis.5b00032

8. MINBIOLE KPC, JENNINGS MC, ATOR LE, BLACK JW, GRENIER MC, LADOW JE, CARAN KL, SEIFERT K, WUEST WM 2016 From antimicrobial activity to mechanism of resistance: the multifaceted role of simple quaternary ammonium compounds in bacterial eradication. Tetrahedron 72(25): 35593566 https://doi.org/10.1016/j.tet.2016.01.014

9. ALLEN RA, JENNINGS MC, MITCHELL MA, AL-KHALIFA SE, WUEST WM, MINBIOLE KPC 2017 Ester- and amidecontaining multiQACs: Exploring multicationic soft antimicrobial agents. Bioorganic Med Chem Lett 27(10): 2107-2112 https:// doi.org/10.1016/j.bmcl.2017.03.077

10. BAYER AS, KUPFERWASSER LI, BROWN MH, SKURRAY RA, GRKOVIC S, JONES T, MUKHOPADHAYK, YEAMAN M R 2006 Low-level resistance of Staphylococcus aureus to thrombin-induced platelet microbicidal protein 1 in vitro associated with qac $A$ gene carriage is independent of multidrug efflux pump activity. Antimicrob Agents Chemother 50(7): 2448-2454 https://doi. org/10.1128/AAC.00028-06

11. PAULSEN IT, BROWN MH, LITTLEJOHN TG, MITCHELL BA, SKURRAY RA 1996 Multidrug resistance proteins QacA and QacB from Staphylococcus aureus: membrane topology and iden- tification of residues involved in substrate specificity. Microbiology 93: 3630-3635

12. BROWN MH, SKURRAY RA 2001 Staphylococcal multidrug efflux protein QacA. J Mol Microbiol Biotechnol 3(2): 163-170

13. SUNDE M, LANGSRUD $S$, YAZDANKHAH SP, HEGSTAD K, LUNESTAD BT, SCHEIE AA 2010 Does the wide use of quaternary ammonium compounds enhance the selection and spread of antimicrobial resistance and thus threaten our health? Microb Drug Resist 16(2): 91-104 https://doi.org/10.1089/ mdr.2009.0120

14. JENNINGS MC, FORMAN ME, DUGGAN SM, MINBIOLE KPC, WUEST WM 2017 Efflux pumps may not be the major drivers of QAC resistance in methicillin-resistant Staphylococcus aureus. ChemMedChem 18(16): 1573-1577 https://doi. org/10.1161/CIRCULATIONAHA.114.010270.Hospital

15. SCHUMACHER MA, MILLER MC, GRKOVIC S, BROWN MH, SKURRAY RA, BRENNAN RG 2002 Structural basis for cooperative DNA binding by two dimers of the multidrug-binding protein QacR. EMBO J 21(9): 1210-1218 https://doi. org/10.1093/emboj/21.9.2301

16. AHLSTRÖM B, THOMPSON RA, EDEBO L 1999 The effect of hydrocarbon chain length, $\mathrm{pH}$, and temperature on the binding and bactericidal effect of amphiphilic betaine esters on Salmonella tvphimurium. Apmis 107(1-6): 318-324 https://doi. org/10.1111/j.1699-0463.1999.tb01560.x

17. PAVLÍKOVÁ-MOŘICKÁ M, LACKO I, DEVÍNSKY F, MASÁROVÁ L, MLYNARČÍK D 1994 Quantitative relationships between structure and antimicrobial activity of new "soft" bisquaternary ammonium salts. Folia Microbiol 39(3): 176-180 https://doi.org/10.1007/BF02814644

18. GILBERT P, MCBAIN AJ 2003 Potential impact of increased use of biocides in consumer products on prevalence of antibiotic resistance. Clin Microbiol Rev 16(2): 189-208 https://doi. org/10.1128/CMR.16.2.189

19. HOQUE J, AKKAPEDDI P, YARLAGADDA V, UPPU DS, KUMAR P, HALDAR J 2012 Clevable cationic antibacterial aphphiphiles: synthesis, mechanism of action, and cytotoxicities. Langmuir 28(33): 12225-12234 https://doi.org/10.1021/ la302303d

20. HALDAR J, KONDAIAH P, BHATTACHARYA S 2005 Synthesis and antibacterial properties of novel hydrolyzable cationic amphiphiles. Incorporation of multiple head groups leads to impressive antibacterial activity. J Med Chem 48(11): 3823-3831 https://doi.org/10.1021/jm0491061

21. LOFTSSON T, THORSTEINSSON T, HILMARSSON H, HJÁLMARSDÓTTIR M A, KRISTINSSON KG, MÁSSON M 2003 Soft antimicrobial agents: Synthesis and activity of labile environmentally friendly long chain quaternary ammonium compounds. J Med Chem 46(19): 4173-4181 https://doi.org/10.1021/ jm030829z

22. PANIAK TJ, JENNINGS MC, SHANAHAN PC, JOYCE MD, SANTIAGO CN, WUEST WM, MINBIOLE KPC 2014 The antimicrobial activity of mono-, bis-, tris-, and tetracationic amphiphiles derived from simple polyamine platforms. Bioorganic Med Chem Lett 24(24): 5824-5828 https://doi.org/10.1016/j. bmcl.2014.10.018

23. ATOR LE, JENNINGS MC, MCGETTIGAN AR, PAUL JJ, WUEST WM, MINBIOLE KPC 2014 Beyond paraquats: dialkyl 3,3'- and 3,4'-bipyridinium amphiphiles as antibacterial agents. Bioorganic Med Chem Lett 24(16): 3706-3709 https://doi. org/10.1016/j.bmcl.2014.07.024

24. GRENIER MC, DAVIS RW, WILSON-HENJUM KL, LADOW JE, BLACK JW, CARAN KL, SEIFERTK, MINBIOLE KPC 2012 The antibacterial activity of 4,4'-bipyridinium amphiphiles with conventional, bicephalic and gemini architectures. 
Bioorganic Med Chem Lett 22(12): 4055-4058 https://doi. org/10.1016/j.bmcl.2012.04.079

25. JOYCE MD, JENNINGS MC, SANTIAGO CN, FLETCHER MH, WUEST WM, MINBIOLE KPC 2016 Natural productderived quaternary ammonium compounds with potent antimicrobial activity. J Antibiot 69(4):344-347 https://doi.org/10.1038/ ja.2015.107

26. LI N, LIU D, DAI JK, WANG JY, WANG JR 2019 Synthesis and in vitro antibacterial activity of quaternized 10 -methoxycanthin6-one derivatives. Molecules 24(8): 1-12 https://doi.org/10.3390/ molecules 24081553

27. HAMAMA WS, ABD EL-MAGID OM, ZOOROB HH 2006 Chemistry of quinuclidines as nitrogen bicyclic bridged-ring structures. J Heterocycl Chem 43(6): 1397-1420 https://doi. org $/ 10.1002 /$ jhet. 5570430601

28. MASHOVSKY M, YAKHONTOVA I 1969 Relationship between the chemical structure and pharmacological activity in a series of synthetic quinuclidine derivatives. Prog Drug Res 13: 293-339

29. VENKATESWARAN A, REDDY YT, SONAR VN, MUTHUSAMY V, CROOKS PA, FREEMAN ML, SEKHAR KR 2010 Antiangiogenic properties of substituted (Z)-( \pm )-2-(N- benzylindol-3-ylmethylene)quinuclidin-3-ol/one analogs and their derivatives. Bioorg Med Chem Lett 20(24): 7323-7326 https://doi. org $/ 10.1021 / n 1061786 n$.Core-Shell

30. CAMMERER SB, JIMENEZ C, JONES S, GROS L, LORENTE SO, RODRIGUES C, RODRIGUES JCF, CALDERA A, PEREZ LMR, DA SOUZA W, KAISER M, BRUN R, URBINA JA, PACANOWSKA DG, GILBERT IH 2007 Quinuclidine derivatives as potential antiparasitics. Antimicrob Agents Chemother 51(11): 4049-4061 https://doi.org/10.1128/AAC.00205-07

31. DE MACEDO-SILVA ST, VISBAL G, URBINA JA, DE SOUZA W, RODRIGUES JCF 2015 Potent in vitro antiproliferative synergism of combinations of ergosterol biosynthesis inhibitors against Leishmania amazonensis. Antimicrob Agents Chemother 59(10): 6402-6418 https://doi.org/10.1128/AAC.01150-15

32. ODŽAK R, ŠPRUNG M, SOLDO B, SKOČIBUŠIĆ M, GUDELJ M, PRIMOŽIČ I 2017 Quaternary salts derived from 3 -substituted quinuclidine as potential antioxidative and antimicrobial agents. Open Chem 15(1):320-331 https://doi.org/10.1515/ chem-2017-0031

33. BOŠKOVIĆ P, ŠPRUNG M, BAZINA L, SOLDO B ODŽAK R 2020 The aggregation behavior and antioxidative activity of amphiphilic surfactants based on quinuclidin-3-ol. J Surfactants Deterg 23(1): 207-214 https://doi.org/10.1002/jsde.12348

34. CHAN FY, SUN N, NEVES MAC, LAM PCH, CHUNG WH, WONG LK, CHOW HY, MA DL, CHAN PH, LEUNG YC, CHAN TH, ABAGYAN R, WONG KY 2013 Identification of a new class of FtsZ inhibitors by structure-based design and in vitro screening. J Chem Inf Model 53(8): 2131-2140 https://doi. org/10.1021/ci400203f

35. CHAN FY, SUN N, LEUNG YC, WONG KY 2015 Antimicrobial activity of a quinuclidine-based FtsZ inhibitor and its synergistic potential with $\beta$-lactam antibiotics. J Antibiot 68: 253-258 https://doi.org/10.1038/ja.2014.140

36. SALAGA M, BLOMSTER LV., PIECHOTA-POLANCZYK A, ZIELINSKA M, JACENIK D, CYGANKIEWICZ AI, KRAJEWSKA WM, MIKKELSEN JD, FICHNA J 2015 Encenicline, an $\alpha 7$ nicotinic acetylcholine receptor partial agonist, reduces immune cell infiltration in the colon and improves experimental colitis in mice. J Pharmacol Exp Ther 356(1): 157-169 https://doi. org/10.1124/jpet.115.228205

37. KEEFE RS, MELTZER HA, DGETLUCK N, GAWRYL M, KOENIG G, MOEBIUS HJ, LOMBARDO I, HILT DC 2015 Randomized, double-blind, placebo-controlled study of encenicline, an $\alpha 7$ nicotinic acetylcholine receptor agonist, as a treatment for cognitive impairment in schizophrenia. Neuropsychopharmacology 40(13): 3053-3060 https://doi.org/10.1038/npp.2015.176

38. BARBIER AJ, HILHORST M, VAN VLIET A, SNYDER P, PALFREYMAN MG, GAWRYL M, DGETLUCK N, MASSARO M, TIESSEN R, TIMMERMAN W, HILT DC 2015 Pharmacodynamics, pharmacokinetics, safety, and tolerability of encenicline, a selective $\alpha 7$ nicotinic receptor partial agonist, in single ascending-dose and bioavailability studies. Clin Ther 37(2): 311324 https://doi.org/10.1016/j.clinthera.2014.09.013

39. RADMAN KASTELIC A, ODŽAK R, PEZDIRC I, SOVIĆ K, HRENAR T, ČIPAK GAŠPAROVIĆ A, SKOČIBUŠIĆ M, PRIMOŽIČ I 2019 New and potent quinuclidine-based antimicrobial agents. Molecules 24(14): 1-17 https://doi.org/10.3390/ molecules 24142675

40. MASHKOVSKY MD, YAKHONTOV LN, CHURYUKANOV VV 1986 Quinuclidinium compounds - new neuromuscular blocking agents: basic and applied aspects, Presented at the

41. ODŽAK R, TOMIĆ S 2006 3-Amidoquinuclidine derivatives: Synthesis of compounds and inhibition of butyrylcholinesterase. Bioorg Chem 34(2): 90-98 https://doi.org/10.1016/j. bioorg.2006.01.004

42. ODŽAK R, TOMIĆ S 2006 Synthesis of new N-quaternary3-benzamidoquinuclidinium salts. Molecules 11: 726-730 https:// doi.org/10.3390/11090726

43. FITZPATRIK L, LAMBERT R, PENDLEY C, MARTIIN G, BOSTWICK J, AIREY G, PENDLETON R, DECKTOR D 1990 RG 12915, a potent hydroxytryptamine3 antagonist that i san orally effective inhibitor of cytotoxic drug-induced emesis in the ferret and dog. J Pharmacol Exp Ther 254: 450-455

44. RACHWALSKI M, VERMUE N, RUTJES FPJT 2013 Recent advances in enzymatic and chemical deracemisation of racemic compounds. Chem Soc Rev 42(24): 9268-9282 https://doi. org $/ 10.1039 / \cos 60175 \mathrm{~g}$

45. ODŽAK R, PRIMOŽIĆ I, TOMIĆ S 2007 3-Amidoquinuclidine derivatives: Synthesis and interaction with butyrylcholinesterase. Croat Chem Acta 80(1): 101-107 https://hrcak.srce.hr/12830

46. PRIMOŽIČ I, HRENAR T, TOMIĆ S 2012 Binding modes of quinuclidinium esters to butyrylcholinesterase. Croat Chem Acta 85(1): 77-83 https://doi.org/10.5562/cca2060

47. PRIMOŽIČ I, BOLANT M, RAMIC A, TOMIC S 2012 Preparation of novel meta- and para-substituted n-benzyl protected quinuclidine esters and their resolution with butyrylcholinesterase. Molecules 17(1): 786-795 https://doi.org/10.3390/molecules17010786

48. PRIMOŽIČ I, TOMIĆ S 2011 Influence of the acyl moiety on the hydrolysis of quinuclidinium esters catalyzed by butyrylcholinesterase. Croat Chem Acta 84(2): 245-249 https://doi.org/10.5562/ cca1829

49. SKOČIBUŠIĆ M, ODŽAK R, ŠTEFANIĆ Z, KRIŽIĆ I, KRIŠTO L, JOVIĆ O, HRENAR T, PRIMOŽIČ I, JURAŠIN D 2016 Structure-property relationship of quinuclidinium surfactants-Towards multifunctional biologically active molecules. Colloids Surfaces B Biointerfaces 140: 548-559 https://doi. org/10.1016/j.colsurfb.2015.11.023

50. ODŽAK R, ŠPRUNG M, SOLDO B, SKOČIBUŠIĆ $M$, GUDELJ M, MUIĆ A, and PRIMOŽIÈNES I 2017 Quaternary salts derived from 3 -substituted quinuclidine as potential antioxidative and antimicrobial agents. Open Chem 15(1): https://doi. org/10.1515/chem-2017-0031

51. BAZINA L, MARAVIĆ A, KRCE L, SOLDO B, ODŽAK R, POPOVIĆ VB, AVIANI I, PRIMOŽIČ I, ŠPRUNG M 2019 Discovery of novel quaternary ammonium compounds based on quinuclidine-3-ol as new potential antimicrobial candidates. Eur J Med Chem 163: 626-635 https://doi.org/10.1016/j.ejmech.2018.12.023 